\title{
Modeling of software agents' societies in knowledge-based organizations. The results of the study.
}

\author{
Mariusz Żytniewski \\ University of Economics in \\ Katowice 1 Maja 50, 40-287 \\ Katowice +48322577277 \\ zyto@ue.katowice.pl
}

\author{
Andrzej Sołtysik \\ University of Economics in \\ Katowice 1 Maja 50, 40-287 \\ Katowice +48 322577277 \\ soltys@ue.katowice.pl
}

\author{
Anna Sołtysik-Piorunkiewicz \\ University of Economics in \\ Katowice 1 Maja 50, 40-287 \\ Katowice +48322577277 \\ apiorunkiewicz@ue.katowice.pl
}

\author{
Bartosz Kopka \\ University of Economics in \\ Katowice 1 Maja 50, 40-287 \\ Katowice +48322577277 \\ bartosz.kopka@ue.katowice.pl
}

\begin{abstract}
Modern organizations, knowledge-based organizations in particular, seek new IT solutions supporting business processes and knowledge management realized by them. One of the solutions, postulated by the authors supporting the actions of such organizations may be computer software in the form of software agents, considered in our study in terms of software agents society. The purpose of this article is to analyze the results of authors' three-year study on the modeling aspect of the software agents society in knowledge-based organizations. The paper presents theoretical issues connected with the use of knowledge management systems in organisations, partial results of interviews with developers of agent solutions in Poland, a proposal of a methodology for designing agent societies, elements of a developed prototype of an agent solution and findings of qualitative research in the area of usability of software agents.
\end{abstract}

\section{INTRODUCTION}

$\mathrm{D}$ EVELOPMENT of organization's theory for modern forms of management of the company's action results in that solutions need to adapt their structure and functionality to meet the specific needs of the organization. One example is to look at the management-oriented approach to knowledge, which is seen as an important organization's resource. Such knowledge, perceived in the literature as an overt or covert knowledge, is an essential part of business processes that such organizations implement. Information systems, which will support organizations aware of the knowledge processing content, should support on one hand its codification, so that the knowledge partnership could be stored as a resource system used by the organization and its employees, and on the other hand the methodology to support the modeling of such systems should support its codification changing tacit knowledge into overt. Solutions, which according to the authors have the indicated characteristics, are agent systems.

The purpose of this article is to analyze the results of the authors' three-year study on the modeling aspect of software agents society in knowledge-based organizations. The study conducted by the authors, initiated in 2012 , on the modeling of software agents' society in organizations based on knowledge, were focused on the search for forms of use of software agents in the context of their use in modern organizations and to determine whether these solutions, aided by semantic knowledge representation, contribute to the improvement of business processes. Due to its complexity, first an analysis of the literature in this area was conducted in order to arrange a society of agents in the registration system used in organizations [1] [2] [3]. Further the IT companies, which offer agent-based solutions, have been asked to indicate their main problems of modeling and implementation [4] [5]. As a result, studies on currently used multi-agent platforms [6] and agent systems design methodologies [7] allowed us to propose a modeling methodology of software agents' society [8] [9] [10], it's possible architecture [11][12] and to assess their impact on organizations [13][14][15]. As part of the qualitative research, indepth interviews and research experiments were used. The presented issues have been addressed in chapters.

Chapter 1 and 2 will present the introduction to the theory of knowledge-based organization and knowledge management. In Chapter 3 the results of the 2013 qualitative research in the form of in-depth interviews with companies forming agent-based solutions on the Polish market will be given. Later in Chapter 4, the methodology of modeling software agents society will be shown, focused on the organization's knowledge for agents specification. Chapter 5 will depict partial results of research, carried out in 2014, related to the software agents' usability analysis in promoting knowledge about the organization and the processes occurring in it.

\section{KNOWLEDGE MANAGEMENT IN ORGANIZATIONS}

The concept of knowledge management (KM) was developed to discover tools and methodology of management of knowledge, which was described as one of classical factor of production with land, labor and capital by Drucker [16] . The term of knowledge management is one of the most promotes an integrated approach to identifying, capturing, evaluating, retrieving, and sharing all of an enterprise's information assets. These assets may include databases, documents, policies, procedures, and previously uncaptured expertise and experience in individual workers [17].

Knowledge management system (KMS) is dedicated to help organization to meet its goals and to increase its effectiveness. The literature review shows that there are a multiple definitions of knowledge management system have been proposed in the literature, and debates about this concept have been expressed from a variety of perspectives and positions [18][19][20]. Also there are some models of life cycle knowledge management in organization [21][22]. 
Information and communication technologies (ICT) may play an important role in effectuating the knowledge-based view of the organization to manage the knowledge it possesses [21][17]. KMSs are technologies that support knowledge management in organizations, specifically, knowledge generation, codification, and transfer. Nowadays the impact of modern ICT (interactive communication channels, agent oriented technologies, etc.) in the company due to developing of Web 2.0/3.0, i.e., social media, blogs, micro blogs, forums, wikis, and others, make the impact in knowledge-based organization.

Knowledge-based organizations understand the importance of knowledge in the process of creating a competitive edge and focus on creating value added based on an effective use of knowledge [23]. ICT solutions focused on the aspect of supporting. Such organizations should support business processes that take place in them in the area of creating, processing and sharing a contextual knowledge about them. This results from the fact that knowledge-based organizations focus not only on business processes but also on knowledge management processes which should be treated in such organizations equivalently. Nowadays knowledge management system is facilitated by Web-based ICTs. It is worth underlining, that the majority of companies use well known ICTs, for example: e-mails, online surveys, social networks, Internet forums, business blogs, comments posted on a producer website, business (specialized) portals, online price comparison [24] [25].

The main tools of Web 2.0 allow users to share content with each other and collaborate online. Web 2.0 features are commonly known as postulates, namely the idea that describes the people-oriented approach [26]. The next generation of the Web is Web 3.0 [27], which is no longer focused on the people but on the machine. The idea of Web 3.0 requires not only data, but also the metadata, which is information about the data; it is reflected postulate transformation into a computer network database. This allows data binding on the Internet, taking into account the aspect of meaning, differentiating the data by the machine with the identical record, and also carried out on these data inference. It is an extension of the existing web, but has better connections between the blocks of information by defining the importance of accurate data available. As a result, programs that read the information, called agents, can analyze data, understand their meaning and find the relationships between them, and perform complicated tasks assigned by the users [28]. It is the main reason of implementation Web 3.0 into knowledge management systems in organization. One of the solutions, that can help such organizations, are software agents societies which can support the different stages of knowledge management systems life cycle.

The study shows the kind of models of agent supported organizations [1]:

- Information allocation model - an agent model refers to the way information flows between the organization and its environment, and additionally the influence of the information on the organization, using a software agent.

- The presence of authority's model - the participation of agents as the authorities in a decision mak- ing process relied on two features: modularity and decentralization.

- Organizational norms and culture model - an agent's behavior depends on the organization's historical factors which are contained in the organization's norms and culture,

- Motivating model - the human factor can be subjected to various influences which in the case of the use of agent-based solutions come down to a certain decision imperative of an agent.

There are different functionalities of knowledge management in such a kind of agent supported knowledge-based organization, e.g. in business context, health care context [29], etc. In the context of health care, multi-agent software (MAS) may play an important role in effectuating the knowledge-based view of the e-health organization by enhancing the capability to manage the knowledge it possesses [30] [31]. There is the method of evaluating MAS in ehealth knowledge management system. The model of multiagent knowledge management system is based on [32]:

- knowledge creation about the user,

- knowledge sharing of the presented problem,

- contextual knowledge about the course of the conversation during knowledge distribution,

- knowledge application in the organization.

There is a diversity of areas in medical industry and health care systems that could benefit from systems based on agent technology (especially MAS) [33] [34]: 1) systems diagnosing diseases, 2) systems that recommend treatment, 3) patient history examination systems, 4) the support of palliative care units.

\section{Program Agents' Societies And Problems With THEIR IMPLEMENTATION}

One of the metaphors of embracing agent technologies is to look for purposeful solutions in terms of software agent society [35]. Agent societies used in knowledge-based organizations operate in an environment of ubiquitous communication and are usually aimed at supporting the organization by supporting the processing and distribution of information and knowledge using semantic knowledge representation mechanisms. In the process of developing agent solutions supporting the improvement of business processes in knowledge-based organizations a variety of approaches, depending on their architecture and construction, are used. The use of semantic knowledge representation mechanisms requires that, at the design stage of the system, methods for acquiring and processing knowledge necessary for the operation of agent solutions are set out.

Conducted in 2013 qualitative research have been realized in the form of a series of in-depth interviews with companies which are the creators of agent solutions on the Polish market [4][5]. A dozen of companies were invited for the study but only 5 of them decided to participate.

Studies have shown that the solutions used by respondents overwhelmingly support the human - computer interaction in the context of their possible use as an element of knowledge management systems, and thus can be considered in the context of the interface agents with their own 
codified knowledge base, associated with organizations' information systems and actively participating in the ongoing business processes. As part of the study different manufacturers' approach towards agent solutions supporting the improvement of business processes in organizations based on knowledge have been analyzed and compared. Among the solutions offered to the market in the use of agent technologies in the sphere of supporting business processes in organizations managed by knowledge, the vast majority are socalled "virtual advisors" showing, in accordance with the adopted typology, lowest level of socialization [30]. One of the important issues raised in the context of the study was to identify the workshop used by vendors of agent solutions on the stage of their development. In this context, the focus was mainly concentrated on methodologies of creating agent solutions. Methodologies used in the construction of agent systems, what was highlighted by the creators of solutions examined, are focused mainly on their architecture, but only to a small extent allow the modeling of system knowledge. There are no proven solutions that are using a methodical approach to the modeling of knowledge representation semantic mechanisms to the needs of agent structures. Respondents confirmed the heterogeneity of methodologies appropriate to the solutions they use, the design of which requires, on one hand the reference to the issues of software development methods, and on the second engineering theory of knowledge, which is required in the context of agents' knowledge base modeling. In addition to the problems of methodology, the respondents pointed to the need for finding methods to assess the impact of the solutions they create on the organization and its environment operation.

Despite differences in the details of the used methodologies design, or the tools used, companies generally agree on the stages of agent-based solutions implementation. In simple terms it can be assumed that this process is based on four main processes. The first one is to analyze and gather information from a user under which the knowledge an agent will have will be worded. Since the information comes from a variety of sources such as individual interviews, search for paper and electronic documents related to the user, and acquired knowledge is not always codified in clear and understandable manner, it is necessary to systematize this information. The next step is to design a model of this knowledge, systematization and arrangement in a certain and clear structure for the agent which will enable it to recognize the thread and giving the user the right answers. The next step is to implement the agent system. The last stage of testing the system is usually the user's input and feedback concerning its functioning. Feedback information from the customer allow us to evaluate whether the knowledge, which was introduced to an agent is correct, if something has been omitted, supplemented, whether the range or essence of knowledge was in some way changed. Then this knowledge should be updated. However, despite applying own methodologies the companies base on proven tools based on UML modeling structures to facilitate knowledge sets, allowing for structuring knowledge to describe some of the relations in the knowledge base, the design of systems architecture of agent.
Virtually all respondents covered by the conducted survey declared that the process of developing agent solutions in their company is more or less consistent with the outlined above methodological scheme. However, even if any particular methodology was not specified, it does not mean taking chaotic and random actions, but consistent common-sense approach, using necessary resources. Most differences in the used approaches are declared in the process of knowledge acquisition.

After implementation of the solution manufacturers attach great importance to feedback from the customer, confirming the correctness of topicality and completeness of the knowledge that was introduced to agent.

With the increasing number of implemented agent systems and their complexity merits, there is a natural need to systematize the knowledge concerning the activities undertaken and their standardization. The use of established methodologies in the implementation of solutions is not disputed by principle, but the very process of implementing the chosen methodology into force is not carried without complications. Among the fundamental problems that arise in the implementation of methodologies indicated by the respondents two groups were dominating:

The first group of problems of objective nature related to the need of increasing the workload associated with the introduction and updating adopted methodological solutions and methods and tools for their implementation. Even recognized methodologies, including a set of procedures, are subject to constant alteration forced by changing organizational and economic conditions resulting in assembly and aggregating new knowledge. According to the respondents implementation of the new system, as well as an agent system, often creates necessity to abandon the previously developed business process execution mode. According to the respondents, implementation and then maintaining particular solution require additional labor, which generally is not enthusiastically accepted by both the contractors of project tasks and team management

The second group of difficulties are the unpredictable problems subjectively linked to specific persons associated with the solutions' life cycle. Indicated by the respondents fear of change, loss of autonomy, wont to existing, not always fully formalized mode, the impression of redundancy of seemingly unnecessary documents required for the execution of implementation makes it difficult to maintain and care for the implemented solution.

A very important aspect in the context of the use of approved methodologies for projects involving complex, partly autonomous structure of software agents society, is their specificity and complexity that result in multiplication of methodological problems encountered in the implementation of individual solutions. At the same time manufacturers of commercially available software emphasized the lack of experience while working on more complex systems. None of the respondents did not declare directly of the implementation of solutions involving cooperation of more agents within a specific software agents' society. 
Depicted here problems caused, that the authors' study have been directed to the aspect of modeling agents' society in the context of the methodological design aspect of such solutions and to develop a method to assess the impact of software agents on the environment in the context of the human - computer interaction. For this purpose, it became reasonable to conduct a comprehensive analysis of the available methodologies and propose the best possible methodology allowing for the implementation of software agents' society. The specificity, diversity and complexity of software agents' society designed to stimulate organizational processes in an organization managed by knowledge, forces the establishment of a transparent and universal model. Options include the use of ready methodologies developed by the companies with years of experience in developing agent solutions, or to create a proprietary methodology based on own experience, supplemented with elements taken from corporate methodologies. To conclude this aspect of research, three main aspects should be noted, which according to the authors should support the defined methodology, supporting the implementation of the agent system in organizations. First is the focus on supporting the business processes modeling in organizations. Its purpose is to better understand business conditions for which the organization's agent system is created by the designers and future users of the solution. Second aspect is the agents society architecture modeling which will be aiding this business process. Targeting organizations for the classic methods of semiformal defining the architecture of the system in the form of UML causes that in case of modeling agents' society it should also be used. The final element is the modeling of knowledge that must be considered in the context of the business process involving people and software agents. Methodology applied here should support the codification of knowledge in a way that allows its understanding and application by both: the users and agents. This aspect is crucial in the context of business process integration and knowledge management systems, where the task of developed methodology should be an indication of the use of codified knowledge in the framework of business processes in the organization.

\section{Methodological Aspects of the Software AGENTS' SOCIETIES DESIGNING}

Conducted interviews indicated that currently created agent-based solutions offered by the companies relate to individual agent solutions. One of these aspects, that caused the lack of implementation in the area of multi-agent systems, was to identify the problems with the integration of knowledge abstracted within the agent system. Therefore, one of the research aspects was to develop proposals for taking up modeling methodology of software agents' society in the context of highest level of agents' socialization, which will focus on the aspect of system's semantic knowledge codification methods and business processes organization. In order to develop such methodology a number of multiagent platforms [6] and methodologies [7] available in the literature and methods of agent design solutions [11] were tested. From the modern organizations' point of view, where organizational knowledge is a key aspect of system design, an indication of how multi-agent modeling environment with a strong focus on knowledge of the system becomes necessary, which the methodologies presented here do not show. None of analyzed methodologies [7] fully define organization's ontology, social relationships. Only three do this in limited way where designer is usually able to define only concepts of agent ontology. Also the mechanism of agent's interaction with the environment is not well realized by analyzed methodologies. Comparative analysis, at the stage of the assumptions related the to design of multi-agent system indicated, that the agent society, through the used methodology, will have limited functionality. The result of the study was to offer the methodology shown in chapter [8].

This methodology was created as a combination of software agents' society design good practice, ontologies design methods and BPMN notation used for the purpose of analyzing the requirements for the created agents' society in the context of the organization it's supposed to support.

The proposed methodology consists of 8 stages, which include:

1. Analysis and development of business process

1.1. Specification of organizations involved in the process and the posts performing the tasks.

1.2. Determination of relationships inside the organization. At this stage the relationship is defined within the organizational structure that supports the system. In case of an organization it is a structure linking the different departments and the process' participants positions.

1.3. Defining the rules of starting and ending the process.

1.4. Diagnosing the business process' tasks.

1.5. Diagnosing the business process' events.

1.6. Defining the conditions governing decision gates.

1.7. Determining the extent of agent's support of a specific task (realization of tasks, assisting the task, none)

2. Resources' identification of in agents' society setting

2.1 Identification of inputs and outputs of the main task

2.2 Identification of resources in the form of services or external data

3. Analysis of the roles and responsibilities of agents' society

3.1 Defining the tasks carried out in the agent society

3.2 Defining the roles of agents in the system

3.3 Diagnosing emergency situations (events)

3.4 Defining the inputs and outputs based on events

4. Determining the hierarchical structure of the relationship inside the organization 
4.1 Reference of the organizational structure with the main tasks carried out by agents

4.2 Determination of organization's internal relationships within the agent society

5. Determination of the extent of agent societies' knowledge

5.1 Identification of knowledge range of agent society

5.2 Identification of the resources provided by agent societies

6. Preliminary definition of agents' internal architecture

6.1 Determining agent's classes

6.2 Assigning agents' classes to roles

6.3 Assigning agents' classes to resources

7. Essential definition of the agents' internal architecture

7.1 Agent knowledge specification

7.2 Defining agent's behavior

\section{Designing the interaction between agents}

The proposed approach for agents' society modeling is considered in terms of the heterogeneous construction agents' societies and determines the combination of best practices for agent solutions modeling to support business processes within the organization's information systems. In particular, this methodology is dedicated for knowledgebased organizations through its focus on modeling of the organization's knowledge using semantic mechanisms of representation.

The proposed methodology has been developed upon the experience regarding the developed prototype of agentbased solutions supporting the operation of the organization and developed in the context of building solutions supporting the interaction of users within the business processes in which they participate [12].

Depicted in the [12] prototype of agents' society was used to evaluate elements of the methodology and pointed to possible applications of agents' society to assist the interaction processes between users.

For the purpose of prototype solution realization BPMN process models were paid and extending the BPMN notation was proposed by a number of new artifacts used in the agents' society modeling process, based on the methodology presented previously. Table 1 present the main artifacts.

As a result, it became possible to develop elements of a modeler supporting the codification of knowledge about processes which involve users in accordance with BPMN notation and allowing to define the knowledge resources of the organization. Figure 1 presents such example.

Elements of the proposed methodology also served to develop a tool that aids software agents' usability analysis in the process of sharing knowledge in the organization's environment. The approach proposed herein offers the following advantages:

- Extending currently used standards for describing business processes to include sources of knowledge
TABLE 1.

PROPOSED ARTIFACTS

\begin{tabular}{|c|c|}
\hline & $\begin{array}{l}\text { Interface agent - designates possible applications of an } \\
\text { interface agent as an element supporting the } \\
\text { performance of a specific task by the user. It allows the } \\
\text { user to go into the mode of evaluation of an agent's } \\
\text { usefulness and use it to support the user's actions. }\end{array}$ \\
\hline & $\begin{array}{l}\text { A multi-agent system - designates a possible } \\
\text { application of a multi-agent system to substitute the } \\
\text { user or prepare a specific knowledge resource that will } \\
\text { be necessary in the decision making process. }\end{array}$ \\
\hline & $\begin{array}{l}\text { Knowledge resource - designates a specific knowledge } \\
\text { resource in knowledge portal or the Internet that can be } \\
\text { indicated to the user. It can be a document, web } \\
\text { service, URL identifier. }\end{array}$ \\
\hline & $\begin{array}{l}\text { onsultant - designates a specific person who has the } \\
\text { levant knowledge about the performance of this task. }\end{array}$ \\
\hline
\end{tabular}

that supports the performance of users' tasks (in the context of the process, place and time).

- Enabling direct integration of organisational knowledge within any business processes taking place in an organisation within the scope of the process in which this knowledge should be used and the task that it supports.

- Automating processes of assessing the functioning of knowledge management systems in terms of their usefulness in supporting business processes.

- Generating new organisational knowledge at the interface of business processes and knowledge management.

- Using semantic mechanisms for knowledge description for easier integration of possessed knowledge with internal organisational knowledge.

- Independent operation from used IT solutions and enabling integration of any knowledge management systems and a process-oriented solution.

In order for agent systems to support business processes, it is necessary to develop tools facilitating the evaluation of an agent's usability in the process of performing users' tasks.

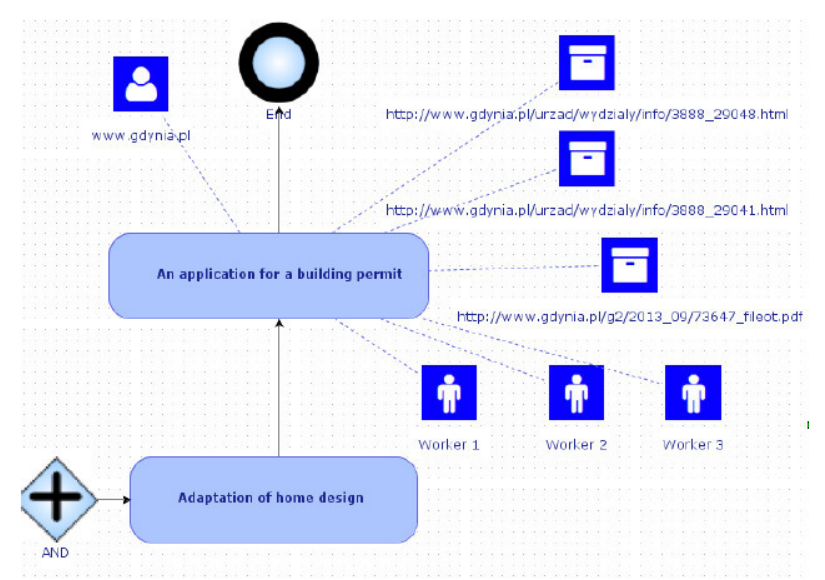

Figure 1. Proposed extension of BPMN notation 


\section{SOFTWARE AGENTS' USABILITY}

As part of the conducted qualitative research it was necessary to determine how software agents' societies improve business processes in organizations based on knowledge. On the basis of the study, creators of agent solutions in Poland were diagnosed and a test method allowing for evaluation of the usefulness of agents in the context of human - computer interaction was proposed - AUKP - Agent Usefulness and Knowledge Propagation analysis method (figure 2).

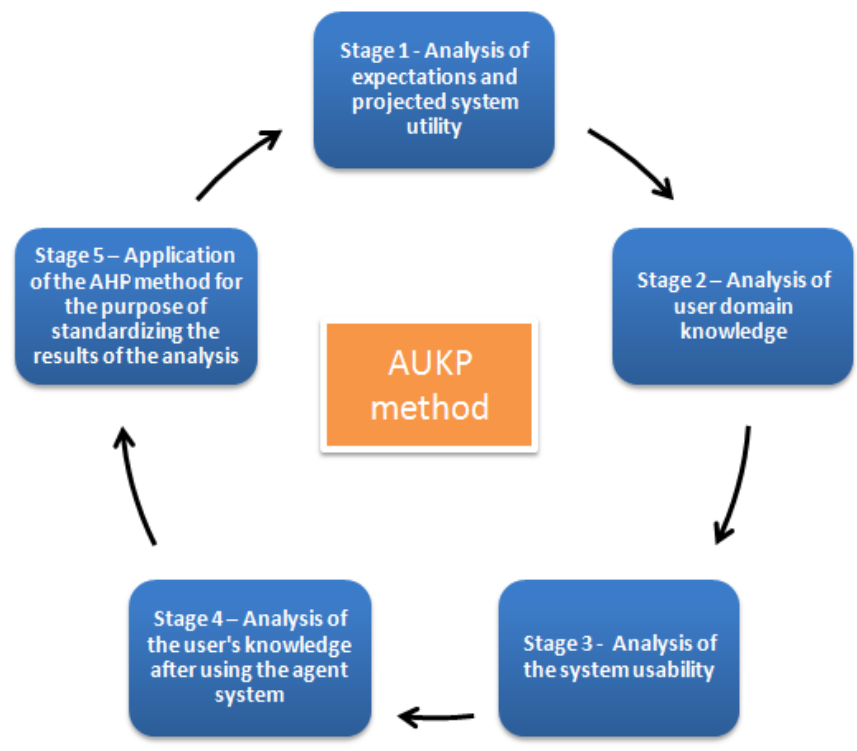

Figure 2. Agent Usefulness and Knowledge Propagation analysis method

During the tests of usability of software agents implemented in organizations, the analysis was conducted in the following stages [15]:

- Analysis of expectations and projected system usability. Aim: determine the expectations of the users in relation to the agent system and its functionality. Proposed method: research survey analyzing the significance of the basic indicators of the system usability.

- Analysis of user domain knowledge. Aim: determine the user's base knowledge in terms of the domain aided by the agent system. Proposed method: survey of knowledge which the user obtains as a result of working with the agent system.

- Analysis of the system usability. Aim: determine the values of the specific indicators of the assessment of the system usability for the user and the organization. Proposed method: direct analysis of the agent system's operation.

- Analysis of the user's knowledge after using the agent system. Aim: to determine the user's knowledge in the field supported by the agent system after using the system. Proposed method: survey of knowledge obtained by the user as a result of working with the agent system (as in stage 1).
- Application of the AHP method for standardizing the results of the analysis. Aim: standardization of the results with regard to users' expectations for a comparative analysis of agent systems. Proposed method: application of the AHP method based on the results obtained in stage 1 and stage 3 .

First, an analysis of previously conducted research on the human - computer interaction in the context of agent usability testing environments was performed. These studies have shown objectivity of examining the usability in terms of the agents' impact on the users. The assumptions concerning the developed method and the results of the conducted experiments are discussed in more detail in the works [13][14] [15]. In these studies researchers assumed, that in accordance with the concept of utility, it is necessary to refer to the analysis of effectiveness, efficiency, satisfaction and propagation/dissemination of agent system's knowledge. For this purpose, the process evaluation model for specified factors within the HCI theory was developed and 102 research experiments were carried out, which aim was to evaluate the operation of three software agents. The results confirmed, that in the group of users and agents can be indicated, that the agent-based solutions contribute to the improvement of business processes in which they participate by improving customer satisfaction and propagation/dissemination of knowledge among users regarding the organization and the processes, in which the organization and the business process recipient participate.

The final results was given: analysis of the general level of satisfaction shows that for users of software agents that were used for experiment satisfactory level was above 0,6 ; also all agents reached knowledge propagation indicator above 0,75 .

Satisfaction and knowledge dissemination assume values from 0 to 1 , where 1 is the highest indicator of satisfaction and the highest level of knowledge propagation/dissemination.

Next two parameters (main effectiveness and partial effectiveness) assume values from -1 to 1 . Values above 0 mean that the system is effective, whereas values below $0-$ lack of the agent's effectiveness. All agents gained measures of effectiveness (main) $>0$ and effectiveness (partial) $>0$, which can be interpreted as the possibility of implementation of indicated main goals by users and shows that the answers generated by an agent were correct.

The last parameter indicates the number of agent objectives performed per a minute. The conducted research has also showed that agent $\mathrm{C}$ (with the result of 3.5 of an objective per minute) achieved the highest performance compared to agent $\mathrm{B}$ ( 3 objective per minute) and agent $\mathrm{A}$ (2.5 goal per minute).

All aggregate results shown here revealed, that in the case where it is possible to identify high efficiency of agents and their productivity, users indicated high levels of satisfaction and knowledge gain. What is characteristic, increased productivity of agents and their effectiveness, influenced the increase of user's satisfaction and the amount of knowledge they acquired. 


\section{CONCLUSION}

As indicated in the article, the theory of modeling the software agents' society is a complex research problem, particularly in the context of their use as a solution supporting the selected type of organization. Developing the assessment methods of the agents' impact on the processes taking place in organizations and supporting their modeling methodologies, required to refer not only to the current state of research in this area, but also to focus on the essence of organizations for the purpose for which they will be developed. The developed methodology, from the organization's point of view, supports the codification of knowledge that is contained herein and contributes to a better understanding of business processes that take place within. Such an approach improves the process of organisational knowledge integration within the modelled society of software agents and allows the relationships of the company's organisational structure to be mapped within a specific society of agents. The next step in the development of this methodology may be extending it by elements of modelling trust and reputation within the agent society being developed.

The proposed assessment method allows for indication whether the influence of agents on the processes that are related to the operation of the organization is visible. The conducted experiments proved that the currently used agent systems in organizations improve ongoing business processes, allow for the improvement of customer satisfaction and help to propagate the knowledge about the organization and its processes. The proposed method, which is based on the assumptions of agents' interaction with users, can be used with any software agents that have an interface ensuring communication with the user. The proposed approach, in accordance with the accepted criterion of usability, indicates validity of an analysis of knowledge propagation and satisfaction indicators, by which the impact of agents on business process participants can be determined, as well as effectiveness and performance indicators, which allow the agent itself to be assessed. The experiment examined the interaction between the human being and computer, but the developed indicators of agents' effectiveness and performance can be also used in the process of interaction between agents in a given society.

\section{ACKNOWLEDGMENT}

The project was financed from the funds of National Science Centre 2011/03/D/HS4/00782.

\section{REFERENCES}

[1] A. Sołtysik-Piorunkiewicz, M. Żytniewski "Software Agent Societies for Process Management in Knowledge-Based Organization" [in:] Proceedings of the 14th European Conference on Knowledge Management, Volume 2, ACPI, UK, 2013, pp. 661-669

[2] M. Żytniewski "Application of the software agents society in the knowledge management system life cycle " [in:] Cognition and Creativity Support Systems ed. M. Pańkowska, S. Stanek, H. Sroka, Publishing House of the University of Economics in Katowice, 2013 pp. 191-201.

[3] A. Sołtysik-Piorunkiewicz "The development of mobile Internet technology and ubiquitous communication in a knowledge-based organization" [in:] The Online Journal of Applied Knowledge Management (OJAKM), Volume 1, Issue 1, 2013, pp 29-41

[4] M Żytniewski, R. Kowal, A. Sołtysik "Creation of Software Agents' Society from the Perspective of Implementation Companies. The Ad- vantages of Their Use, the Problems of Construction and Unique Features" [in:] Research Papers of the Wroclaw University of Economics in series "Business Informatics", Publishing House of Wrocław University of Economics 3(29), 2013, pp. 162-171

[5] M. Żytniewski, R. Kowal, A. Sołtysik "The outcomes of the research in areas of application and impact of software agents societies to organizations so far. Examples of implementation in Polish companies" [in:] "Annals of Computer Science and Information Systems, Volume 1" Proceedings of the 2013 Federated Conference on Computer Science and Information Systems, pp 1181 - 1187

[6] M. Żytniewski, M. Klement "Analiza porównawcza wybranych platform wieloagentowych” [in:] Informatyka 2 Przyszłości 30 Lat Informatyki Na Wydziale Zarządzania UW, ed. J. Kisielnicki, W. Chmielarz, T. Parys, Wydawnictwo Naukowe Wydziału Zarządzania Uniwersytetu Warszawskiego, 2015

[7] M. Żytniewski "Comparison of methodologies for agents' software society modeling processes in support for the needs of a knowledgebased organization" In Procedings of 11th International Conference "MULTIMEDIA IN BUSINESS AND MANAGEMENT", Institute of Management Information Systems Management Faculty Częstochowa University of Technology, 2015

[8] M. Żytniewski "Modelowanie systemów agentowych wspomagających organizacje oparte na wiedzy", [in:] "Technologie agentowe w organizacjach opartych na wiedzy" (praca zbiorowa pod redakcją M. Żytniewski), Wydawnictwo Naukowe Uniwersytetu Ekonomicznego w Katowicach, 2015 (after positive review)

[9] M. Żytniewski "Wprowadzenie do teorii społeczności agentów programowych oraz ich zastosowania $w$ organizacjach opartych na wiedzy", [in:] "Technologie agentowe w organizacjach opartych na wiedzy" (praca zbiorowa pod redakcją M. Żytniewski), Wydawnictwo Naukowe Uniwersytetu Ekonomicznego w Katowicach, 2015 (after positive review)

[10] M. Żytniewski. M. Klement "Trust in software agent societies" [in:] The Online Journal of Applied Knowledge Management (OJAKM), 2015 (after positive review)

[11] M. Żytniewski, R. Kowal "Using Software Agents to Enhance the Functionality of Social Knowledge Portal" [in:] "Business Information Systems Workshops" ed. Witold Abramowicz, Springer Lecture Notes in Business Information Processing vol 160, pp 23-34

[12] M. Żytniewski "Integration of knowledge management systems and business processes using multi-agent systems" [in:] Proceedings of the Cooperative Online Organizations conference (presented at the AAMAS'15 Workshop), Turkey, 2015

[13] M. Żytniewski, B. Kopka "Indicators of software agents usability and ergonomic" In Procedings of I. MEDIAL INTERNATIONAL SCIENTIFIC CONFERENCE OF THE SERIES "Decisions in situations of endangerment", The Journal of Science of the Gen. Tadeusz Kosciuszko Military Academy of Land Forces, Wrocław 2015 (after positive review)

[14] B. Kopka, M. Żytniewski "The system ergonomics and usability as measurement of the software agent impact to the organization", in Proceedings of Advances in Ergonomics In Design, Usability \& Special Populations ed. F. Rebelo, M.Soares, Published by AHFE Conference, 2014, pp. 21-34

[15] M. Żytniewski, B. Kopka "The proposition of agents' usability analysis method based on an analysis of Polish enterprises" [in:] Proceedings of the Human Agent Interaction Design and Models conference (presented at the AAMAS'15 Workshop), Turkey, 2015

[16] P. Drucker, Post-capitalist society. Harper Business, New York 1993

[17] E. Turban, D. Leidner, E. McLean, M. Wetherbe, Knowledge management, in Information technology for management: transforming organizations in the digital economy, John Wiley, New Jersey 2006, pp.: 365-405.

[18] I. Nonaka, H. Takeuchi, Knowledge-Creating Company. Oxford University Press, New York, 1995

[19] K.M. Wiig, Knowledge management foundations. Schema Press, Arlington 1993

[20] M.E. Jennex, Knowledge Management: Concepts, Methodologies, Tools and Applications, IGI Publishing Hershey, PA, USA, 2009

[21] T. Davenport, \& L. Prusak, Working knowledge how organizations manage what they know, Boston: Harward Business School Press. 1998

[22] R. Van der Spek, \& A. Spijkervet, Knowledge Management: Dealing intelligently withknowledge. In J. Liebowitz, \& L. Wilcox (Eds.), Knowledge management and its intergrative elements. CRC Press, New York 1997 
[23] W.M. Grudzewski, I. Hejduk, "Knowledge management in enterprises", Difin, Warszawa 2004

[24] E. Ziemba, M. Eisenbardt, "Aktywności prosumenckie z wykorzystaniem technologii informacyjno-komunikacyjnych w świetle badań bezpośrednich" [Research on ICT application towards prosumers' activities]. In A. Nowicki \& D. Jelonek (Eds.), Wiedza i technologie informacyjne w kreowaniu przedsiębiorczości, 101-113. Częstochowa: Publishing House of Wydział Zarządzania Politechniki Częstochowskiej, 2013

[25] E. Ziemba, J. Wielki, The use of corporate portals in managing knowledge on entities operating in the electronic space. In S. Wrycza (Ed.), Proceedings of the Seventh International Conference on Perspectives in Business Informatics Research BIR'2008, 143-157. Gdansk: Gdansk University Press. 2008

[26] A. Sołtysik-Piorunkiewicz "The Telecom Business Strategies: a Comparative Study of Corporate Blogs". MIDI Warszawa 2014

[27] J. Markoff, Entrepreneurs see a web guided by common sense, New York Times, 2006

[28] J. Gołuchowski J. „Wprowadzenie do inżynierii wiedzy”, Difin SA, Warszawa 2011

[29] M. Furmankiewicz, A. Sołtysik-Piorunkiewicz, P. Ziuziański "Artificial intelligence systems for knowledge management in e-health: the study of intelligent software agents" [in:] Latest trends on Systems: 18th International Conference on Systems: Santorini Island, Greece, July $17-21,2014$, str. $551-556$
[30] A. Sołtysik-Piorunkiewicz "Knowledge management impact of information technology Web 2.0/3.0. The case study of agent software technology usability in knowledge management system", AIP Conf. Proc. 1644, 219, 2015, http://dx.doi.org/10.1063/1.4907840.

[31] A. Sołtysik-Piorunkiewicz, M. Furmankiewicz, P. Ziuziański "The method of evaluation of multi-agent software for knowledge management in e-health". [in:] L. Kiełtyka, R. Niedbał (Ed.) Wybrane zastosowania technologii informacyjnych zarządzania w organizacjach, Monografia $\mathrm{Nr}$ 296, Wydawnictwo Politechniki Częstochowskiej, Częstochowa 2015.

[32] A. Sołtysik-Piorunkiewicz, M. Furmankiewicz, P. Ziuziański "Artificial intelligence and multi-agent software for e-health knowledge management system" [in:] Business Informatics (Informatyka Ekonomiczna), Wydawnictwo Uniwersytetu Ekonomicznego we Wrocławiu, Nr 2 (32) / 2014, s. 51-63.

[33] A. Sołtysik-Piorunkiewicz ,Technologie mobilne w zarządzaniu organizacją opartą na wiedzy", [in:] R. Knosala (Ed.) Innowacje w zarządzaniu i inżynierii produkcji, PTZP, Opole 2015

[34] U. Cortés, R. Annicchiarico, C. Urdiales "Agents and Healthcare: Usability and Acceptance", [in:] R. Annicchiarico, U.C. Garcia, C.Urdiales, Agent Technology and e-Health, Birhauser Verlag, Basel, pp. 13, 2008

[35] M. Żytniewski „Rozwój koncepcji społeczności agentów programowych" Europejska przestrzeń komunikacji elektronicznej red. J. Buko, Zeszyty Naukowe Uniwersytetu Szczecińskiego, 2013 